\title{
The shaping and formation of a missional ecclesiology of township congregations in the Mangaung Metro Municipality during COVID-19
}

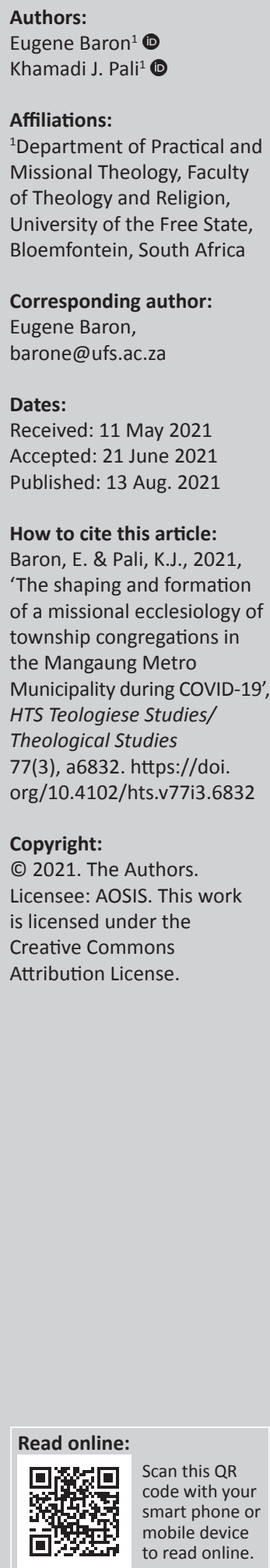

The coronavirus disease 2019 (COVID-19) pandemic caught most organisations, institutions and leaders off-guard, including church leaders. This was not any different in the congregations in the townships of the Mangaung Metro Municipality. The article discusses the responses of the churches in the Mangaung district and poses the question pertinently, 'How did (or not) the churches in the Mangaung district reimagine, restructure, and position themselves prophetically during the COVID-19 pandemic?'. This is done firstly by providing a background to the development of a missional ecclesiology in North America, United Kingdon, and South Africa. Secondly, a discussion will be focused on the characteristics of the congregations which are necessary for developing a missional ecclesiology, in terms of these phases, as argued by Baron and Maponya. However, in the final section it will bring the missional ecclesiological discourse in conversation with the shaping and developing (or not) of a missional ecclesiology in respect of congregations in the township of the Mangaung Metro Municipality. The authors provide some contours for the missional role of the church in the current South African context and the formation of a missional ecclesiology.

Contribution: This article contributes to the missional church discourse in missiology, that has been a conversation within Dutch Reformed Church in South Africa. The authors have been conducting research within mostly Pentecostal church in the township of Mangaung. The article is an attempt to broaden the missional church discussion in terms of region and Pentecostal ecclesiology.

Keywords: missional; missional church; COVID-19; re-imagination; prophetic.

\section{Introduction}

The churches in South Africa were never fully prepared when the coronavirus disease 2019 (COVID-19) pandemic hit the country. This might be because it being a novel pandemic that caused an unprecedented crisis. It caused a crisis in at least three or more identified social areas. Firstly, although this was contested ontologically by some churches in South Africa, it needs to be stated unequivocally, that it is indeed a disease. According to medical scientists around the world, the coronaviruses are (Department of Health 2021):

$[A]$ large family of viruses which may cause illness in animals or humans. In humans, several coronaviruses are known to cause respiratory infections ranging from the common cold to more severe diseases such as Middle East Respiratory Syndrome (MERS) and Severe Acute Respiratory Syndrome (SARS). The most recently discovered Coronavirus causes coronavirus disease COVID-19. (n.p.)

However, since the outbreak of the COVID-19 pandemic in South Africa, it has been interpreted in multiple ways. Firstly, politically the virus was understood to be an instrument used to depopulate people in the world and in particular Africans. This theory is construed in such a way that the world is overpopulated and therefore, there is a need to decrease the number of people. Those espousing this theory would argue that, in Africa, where the population growth is said to be increasing, this coronavirus would be the ideal instrument to facilitate the reduction of the overpopulation. A second conspiracy theory that exists is that economically the coronavirus was understood to be a ploy from the Republic of China which wanted to weaken the economy of the other countries so that its economy can be dominant over the world. Thirdly, religiously the coronavirus was understood in an apocalyptic manner whereby it was assumed to be Satan's attack on churches so that religion, in particular the Christian religion would not grow and people would lapse in their faith. Furthermore, other religious viewpoints that also emerged in South Africa gave rise to the idea that it was God's punishment for the world because of their own sins.

Note: Special Collection: Being a Change Agent in a (Post-) Covid South Africa, sub-edited by Erna Oliver (University of South Africa). 
Irrespective of all these 'conspiracy' theories, it should also be stated that the coronavirus is not the only pandemic that has strained the health system in South Africa and which have become an unavoidable missiological issue. The outbreak of the HIV and AIDS pandemic also became a concern for the church and missiologists that could not be ignored. This has also during its initial stages in the 1980s been subjected to the kind of conspiracy theories as mentioned above. During the outbreak of the COVID-19 pandemic, various existential questions came to the fore, for instance, the involvement of God in these pandemics. This is not a new question within the missiological research domain because it was Madipoane Masenya (2001) that posed a similar question during the HIV and AIDS pandemic in her article entitled, 'Unjust suffering and a silent God'. There were also questions on the contribution of the sin of human beings argued to be the cause for HIV and AIDS in the world. Since the emergence of the HIV and AIDS pandemic there has been a continued missiological reflection on it, and therefore it is not any different when existential questions are again raised during the coronavirus pandemic. A cursory review on missional responses that could be gathered from Missionalia ${ }^{1}$ editions since the 1980s vary. A need developed amongst theologians and missiologists to include the discourse of HIV and AIDS that was mainly a health issue or sociological discussion, as a missiological discussion. Maluleke (2001) was therefore pleading for the need to include the pandemic as part of the theological curriculum at universities' faculties of theology. When there were several responses from the health sector and health professionals, Johannes Siebert would ask the question, 'How can the Bible be used to address the issue of HIV / AIDS?' (Stiebert 2001). There was also a serious concern about the role of the local churches in addressing the health concern (cf. Mboya 2010). The coronavirus pandemic also became a theological, existential issue for congregations in South Africa, as in the case of the HIV and AIDS pandemic, which required also a congregational response.

Nevertheless, the coronavirus also exposed the gross inequalities and the socio-economic crisis, which also called for a deeper missiological reflection. In 2020, the World Health Organization $(\mathrm{WHO})$ reported that the pandemic is not only a health crisis, but also a socio-economic crisis (2020a):

The COVID-19 pandemic has led to a dramatic loss of human life worldwide and presents an unprecedented challenge to public health, food systems and the world of work. The economic and social disruption caused by the pandemic is devastating: tens of millions of people are at risk of falling into extreme poverty, whilst the number of undernourished people, currently estimated at nearly 690 million, could increase by up to 132 million by the end of the year. (n.p.)

Millions of enterprises face an existential threat. Nearly half of the world's 3.3 billion global workforce is at risk of losing their livelihoods. Informal economy workers are particularly vulnerable because the majority lack social protection and access to quality health care and have lost access to productive assets. Without the

1.This is a missiological journal of which David Bosch, the renowned missiologist was the first editor, and include contributions from South Africa and the rest of Africa the first editor, and include contribut
focus on mission and missiology. means to earn an income during lockdowns, many are unable to feed themselves and their families. For most, no income means no food or, at best, less food and less nutritious food. (n.p.)

They argue that the response for the socio-economic crises would be (WHO 2020a):

[A] time for global solidarity and support, especially with the most vulnerable in our societies, particularly in the emerging and developing world. Only together can we overcome the intertwined health and social and economic impacts of the pandemic and prevent its escalation into a protracted humanitarian and food security catastrophe, with the potential loss of already achieved development gains. (n.p.)

The question that this article would interrogate is whether the church re-imagined themselves as missionary in nature. However, it became a crisis in which the church was also called for participation and form part of the key role players to address the situation. The WHO provided guidelines for the church in terms of COVID-19 and stressed the importance of including 'life-saving messages' in their sermons and liturgy, ensuring social distancing, prevent kissing and touching of religious objects, encouraging healthy hygiene, the use of low-technology to maintain community, responding to situations of domestic violence, offering prayers and counselling for sick people, to help others, but also to communicate health protection information to their congregants (WHO 2020b).

The church itself struggled to make theological sense out of what transpired in the world. However, not too long ago, the ecumenical church in South Africa is reminded of its role during a crisis of 'apartheid' (racial segregation). It had to stand in solidarity with the oppressed and for the emancipation and liberation of them from racial oppression. This gave rise to the Kairos Document (KD), as well as one of the daughter churches, the Dutch Reformed Mission Church (DRMC) that drafted a confession (Belhar confession) to address the crisis theologically (NGSK 1986:1). On another front, through the World Alliance of Reformed Churches (WARC), the churches also stood in solidarity with other third world countries to denounce the ecological and economic injustice in the world through the drafting of the ACCRA confession (Baron \& Botha 2020:161). These indeed brought much clarification on the stance of the ecumenical church during those situations of crises of diverse sorts. Moreover, it was evident that it was not only a conceptual clarification, but also a prophetic stance that was taken during such crises. In a recent book, Baron and Botha (2020) also discusses the role of four members of the first moderature on the Uniting Reformed Church in Southern Africa (URCSA), and classified their role - against the vicious system of apartheid - as missional. Baron and Maponya (2020) would equate such a missional role as a prophetic role, because it is in nature a matter for the church of being a witness of God in the world.

In 2004, the South African Partnership for Missional Churches (SAPMC) was born, in collaboration with Communitas at the University of Stellenbosch, of which mainly Dutch 
Reformed Church (DRC) congregations were part, and in 2010 the DRC Synod also adopted a policy document on missional ecclesiology (cf. Marais 2017:65). However, Niemandt (2010:400) mentions that there were later 170 congregations from different denomination that form part of the movement, and out of it 'unique contextual material was developed' that was not only useful for the members locally, but also for the larger international partners. Marais (2017:67) situates this development with the 'transformation' processes, and argue that missional ecclesiology, is more than just developing new programmes to energise people. It is a new 'ecclesiology' (which the missional church movement provides) that would also contribute towards the transformation desperately needed in South Africa. However, striking in Marais's (2017) historical report, not a lot, even fact there is no reflection on mostly township, and Pentecostal churches, particularly participating in the movement at the time of publication, which indeed shows the gap, that also the author would want to address in the research - on various 'missional church' initiative beyond the projects mentioned above.

Although it would be too early to assess the magnitude of the impact (non-impact) of the churches in South Africa during the coronavirus pandemic, it would at least be possible in the interim to discuss to what extent the pandemic shaped and developed a missional ecclesiology by employing the suggestive phases of Baron and Maponya (2020) inter alia, namely, (1) re-imagination, (2) structural changes, and (3) prophetic praxis. ${ }^{2}$ This will serve as a theoretical framework in which the authors will, therefore, discuss the missional positioning of the congregations in the township of the Mangaung township.

\section{Developing a missional ecclesiology: Re-imagine, restructure, prophetical praxis \\ Missional ecclesiology and the process of re- imagining}

It could never be the case that the church's response(s) remains the same at all times/contexts through fulfilling God's mission on earth. This has been argued by David Bosch (1991) in his magnum opus Transforming Mission. The 'reimagining' of the North American Reformed churches in the 1990s emerged out of a cultural crisis of the church in its context. According to Darryl Guder (ed. 1998) who was part of the research think-tank, the Gospel and Our Culture Network (GOCN), during the 1990s, asserts that the:

Christian Church finds itself in a different place in relation to its context. Rather than occupying a central and influential place, North American Christian Churches are increasingly marginalised, so much so that in our urban areas, they represent a minority movement. (p. 60)

As the GOCN the churches itself became a mission field. The churches in the North American context was overwhelmed

2.In their article entitled 'The recovery of the prophetic voice of the church: The adoption of a "missional church" imagination' Baron and Maponya (2020) captures these three phases from their reading and analysis of the Missional Movement in North America. by the cultural changes that emerged and consequently the Reformed Churches had to re-imagine its role in such a context. In the United Kingdom (UK), the Anglican church also had a re-imagining process. Cray (2017) describes how the Anglican church became 'missional':

At the local level there is a new imagination about the forms the church can take for the sake of mission. Missional imagination and missional leadership are being released, often in unexpected places. Instead of being trapped within a tightly defined traditional picture of church, mainline Christians are imagining being church in ways they would not have considered before. Fundamentally this is a grassroots movement of the Spirit. (p. 102)

In the South African context, the churches also had to reimagine their position, and this is well argued by Nico Smith (2002) in which he proposed a focus on the Missio Hominus (mission of the people) as central motif for God's witness in the world. Smith's concern was that the movement towards understanding mission as God's mission might as well be used in a post-apartheid context to discredit the issue of God's mission as one that is for the suffering, vulnerable, poor and oppressed - it is that God's mission. ${ }^{3}$ Much critique could be launched against the argument of Smith, but the point is made that the apartheid context in South Africa led to an ecclesiological and missiological crisis. Burger (2017:29), argues that even the Dutch Reformed Church was challenged to 'reimagine' church, that they had to think different also of some of their church order articles, 'There are practical examples of how unimaginative rules and vested interests in existing practices can - most of the time unintentionally smother the missional movement'.

Furthermore, during the period of apartheid, there was the resurgence of a call to the prophetic voice of the church in South Africa (cf. Kritzinger 2012). Others would, in the postapartheid context, call for a resurgence of the prophetic voice of the church (Baron \& Maponya 2020) as part of an emerging missional ecclesiology. ${ }^{4}$ However, these attempts at finding a missional response were more seeking constructive proposals for the new positioning of the church in South Africa (cf. Makofane \& Botha 2019).

A study by Baron and Maponya (2020) demonstrates that the aspect of ecclesial 'imagination' should not be taken lightly, as this seems to be the first step in a process, during a crisis in the church's context, that causes for the shaping and formation of a missional ecclesiology. This was similar to what has been happening in the North American context. It is also necessary for churches and congregations in the South African context. The subsequent processes they argue are that of restructuring and a prophetic praxis. What is indeed important to note is that the re-imagining process is always emerging during one or the other 'crisis' in society (cultural, social, economic, health, etc.) that compel the church to do so.

3.See a brief discussion on this in Baron's paper entitled 'The Call for African Missional Consciousness through Renewed Mission Praxis in URCSA'. In this article Baron addresses the issue of a shift in the mission paradigm.

4.See also the article of Masuku (2014) in this regard, in which he looks at prophetic praxis within apartheid and post-apartheid context. 
Therefore, the coronavirus in South Africa served such a purpose, as in the North American church in the 1990s confronting the churches in South Africa to re-imagine, what it means to be 'church'.

The COGN argues that their vision for a re-imagined missional ecclesiology has the following affirmations:

1. It is biblical. The Bible attests to God's mission and the formation of a missionary people. Therefore, a missional hermeneutic is important (ed. Guder 1998:11).

2. It is historical. Ecclesiologies are always shaped in terms of a particular culture, and that should be acknowledged. Thus, the church should read its history in terms of the emergence of different ecclesiologies and cultural expressions.

3. It is contextual. All ecclesiologies are developed within a particular cultural context. Therefore, Guder (ed. 1998:11) argues, 'There is but one way to be the church, and that is incarnationally, within a specific church setting'.

4. It is eschatological. "Our doctrine of the church must be developmental and dynamic in nature if we believe that the church is the work of the creating and inspiring Spirit of God and is moving towards God's promised consummation of all things. Neither the church nor its interpretive doctrine may be static" (ed. Guder 1998).

5. It can be practised. A missional ecclesiology should be translated into practice (ed. Guder 1998:12). A missional ecclesiology shapes the church's witness of God in the world.

\section{Missional Ecclesiology and the call for restructuring}

Guder (ed. 1998) explains the structural changes that had to occur within churches after the realisation that the cultural realities in their contexts have changed:

Neither the structures nor the theology of our established Western Traditional Churches is missional. They are shaped by the legacy of Christendom. This is, they have been formed by centuries in which Western civilisation considered itself formally and officially Christian. (pp. 5, 6)

Then he states:

Even when the legal structures of Christendom have been removed (as in North America), the legacy continues as a pattern of powerful traditions, attitudes, and social structures that we describe as 'functional Christendom'. (p. 6)

Guder (ed. 1998) provides some light on what also should be done in a 'crisis' by the church, should it re-imagine its role and allow for restructuring - or should they at all cost resist it?

The shaping [of the church] always moves in two directions. On the one hand, the church understands that under the power of God, the Gospel shapes the culture of a society - its assumptions, its perspectives, its choices. The church knows this because the gospel is always doing that to the very culture that is its own. This gives an indication of God's vision for the church's transforming impact on its context. On the other hand, because the church is incarnational, it also knows that it will always be called to express the gospel within the terms, styles and perspectives of its social context. It will be shaped by that context, just as it will constantly challenge and shape that context. (p. 14)

Guder (ed. 1998) states:

Its vocation to live faithfully to the gospel in a fully contextual manner means that it can sometimes find itself either unfaithful or uncontextual. In addition, the human context that shapes it continues to change. Therefore, the questions of its faithfulness are always fresh ones. The Gospel is never fully and finally discerned so that no further transformation can be expected. The incarnation between the gospel and all human cultures is a dynamic one, and it always lies at the heart of what it means to be the church. (p. 14)

There has been many churches and denominations that has passed the phase, in what Baron and Maponya (2020) refer to as the 're-imagining' phase in missional ecclesiology, but not fully make it part of the praxis of churches. Therefore, Pillay (2017:39) would remind us, that to reflect the desire for 'missional ecclesiology' in vision and mission statements of a church, it is sufficient, but it must become part of the 'DNA of the church'. This is meant by 'restructuring' of Baron and Maponya (2020). Pillay (2017:39) states unequivocally, 'It may be true to say that whilst many denominations in South Africa are thinking missional they are far from the attempt to shape their DNA from a missional perspective'.

\section{Missional Ecclesiology and the call for prophetic praxis}

However, Baron and Maponya (2020) would argue that the church or congregation that allows itself to re-imagine its nature in society during a crisis, as well as subsequently initiate a restructuring process would become 'prophetically' positioned. This includes being witnesses of God in the world in a contextually relevant manner. This was ultimately the goal also for churches in the North American context (as referred to earlier). Guder (ed. 1998) refers to the prophetic positioning of the church in their context, when he states:

The trust of the gospel exposition ... is to define a missionary people whose witness will prophetically challenge precisely those dominant patterns as the church accepts its vocation to be an alternative community. (p. 10)

This prophetic movement is better described by Bevans and Schroeder (2004) who defines it to be in constant dialogue with its context.

\section{Research design and methodology}

The authors followed a qualitative approach. For collection of data, the authors had a workshop with 15 church leaders in the Mangaung township ${ }^{5}$ and then distributed some openended questions which allowed them to report on behalf of

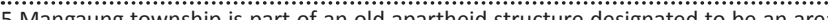
f re of residence for black population near Bloemfontein in the Free State province of South Africa. It is part of Mangaung Metro Municipality which consists of Bloemfontein, Botshabelo, Thaba Nchu, Deneysville, Dewetsdorp, Wepener, and Vanstadensrus. 
their churches their experience of the coronavirus pandemic and how it influenced them to re-imagine, and/or restructure, and act prophetically in the time as township congregations in the Mangaung township.

The church leaders who participated in this research were invited randomly from the congregations in the Mangaung township. The lowest qualifications of the church leaders were grade 12 and the highest qualification was a Master's degree, but majority of these church leaders had at least a Bachelor's degree. In terms of gender, majority were African males in the age group of 35-49 years.

\section{The missional (or not) responses of the Mangaung churches}

This section will discuss the data in the following manner: Firstly, it explains how the church leaders reimagined the concept of coronavirus, church and its mission in the midst of the coronavirus pandemic. Secondly, it discusses how church leaders re-structured or prepared for the restructuring of their ministry in order to adapt and remain relevant to the changing context in the midst of the coronavirus pandemic. Thirdly and lastly, the discussion focuses on the prophetic role of the congregations in their community during the outbreak of the coronavirus pandemic in 2019 in South Africa till the collection of the data from the church leaders.

\section{Re-imagining concepts of the church, mission and coronavirus}

\section{Re-imagining the concept of church during the pandemic}

The manner in which the church leaders recognise the concept of church influences the way in which the mission and leadership of the church are practised. From the responses of our participants, we intended to find out whether their conceptual understanding of the church had some influence on their mission praxis. We, therefore, asked our participants to give us their own understanding of the concept of church. The majority of the participants defined the church as the body of Christ. Their responses were as follows: "The church is the Body of Christ comprised of all those who confess the Lordship of Christ and who seek to live as His true disciples and ambassadors'. 'Church is the body of Christ of which we must always respect it and observe it'. The others' responses on the conceptual definition of church were describing the church as the communion of saints, believers who gathered together to worship God, and 'a person who follow Jesus Christ'.

These responses of the participants could be understood in terms of the church as a mystical union (Dulles 2002:39-54) and/or in terms of the 'Body of Christ model' (Hendriks 2004:48). According to Dulles (2002:50) and Hendriks (2004:50) the emphasis of Body of Christ model is based on the notion of communion with one another, and with God in Christ. It has the propensity to foster ecumenical relationships with those who share the same belief and fellowship. The beneficiaries of love and fellowship of the Body of Christ are those who experienced conversion and received the Holy Spirit. Hence, the goal of the church and its mission is a personal relationship with the Triune God which is manifested in the experience of love and fellowship in the Body of Christ. In summary, this model makes room for the creative role of the Holy Spirit and centralises the issue of relationship which is an essential human need in the midst of world challenges. Despite the positive development of the Body of Christ model, Dulles (2002:52) and Hendriks (2004:51) discusses the weakness of this model as having tendency to allow members of the church to develop an attitude of perfectionism, and triumphalism. Most importantly, this model often lacks a clear sense of identity and mission.

In light of the above discussion on the church as the Body of Christ, we positively observed that majority of the participants do like to be in dialogue with other church leaders and are members of the ecumenical organisations through their participation in the ministers fraternal in the area of the Mangaung township. In these ecumemical organisations participants do fellowship and share love, knowledge and skills to assist each other in the ministry. Because majority of the participants indicated church as the Body of Christ, we intended to find out if they do allow the Holy Spirit to give its creative direction to the ministry of their churches in the midst of the challenges created by the presence of the coronavirus pandemic.

In contrast, further observation revealed that very few of our participants were not part of any ecumenical organisation because of lack of interest or feeling that ecumenical organisations are not useful to them. We did not determine whether this lack of interaction with ecumenical organisation is in relation to the attitude of perfectionism or triumphalism and thus it needs further research. If one's understanding of the concept of the church influences the way one would do mission, to what extent do the participants' churches understand mission?

\section{Re-imagining the notion of mission of the church during the pandemic}

The participants were asked to define how they understand the mission of the church. Their definition is categorised into three groups. The majority of the participants gave a diverse understanding of mission of the church, such as, a process of converting sinners to Christ, soul-winning of sinners, reconciling humanity with God, making Christ known to others, bringing people to God and making people aware of the living God. The other group emphasised mission as proclamation of the gospel for the purpose of making a disciple. The last group of participants raised the aspect of social involvement in mission by acknowledging mission as preaching the gospel for the purpose of changing lives of people for the better, upholding the Great commission in word and deed, reaching out beyond the church, and demonstrating the gospel. 
In light of the above points, it is motivating to realise that the participants' missional understanding centres around God. It involves both proclamation of the gospel and social involvement for the purpose of changing lives of people for the better. In view of this, to what an extent do missional practices of the participants changes lives of people? Do these reach out beyond the church? Or do they demonstrate the living out of the gospel? The responses for the above will be done through analyses of the ministerial practices of the participants since the beginning of the COVID-19 pandemic in South Africa in the year 2020.

\section{Re-imagining the concept of the coronavirus pandemic}

It would also be crucial to determine whether any reimagination took place in terms of reflection on health issues such as the coronavirus pandemic as a missiological issue, that is more than only an issue to be spiritualised. Were the congregations challenged during the pandemic to re-imagine the health challenge also for its social challenges posed? Majority of the participants gave a scientific and religious understanding of the virus. The closest scientific understanding of the coronavirus which is evident through the responses of the participants is that, it is indeed a deadly and infectious virus that is unprecedented and that it causes difficulty in breathing and the significant loss of life. The participants also engaged the issue providing a spiritual interpretation, arguing it to be a fulfilment of the end times prophecy in the Bible and of the second coming of Jesus Christ. Furthermore, the suffering it caused increased the Christians' faith in God and compelled them to depend on Him. Nevertheless, few of the participants responded that they were uncertain how to interpret the phenomenon, whilst others described it as a horrible virus that was employed to attack human beings and to cause huge destruction to the economy and life in general. Lastly, other participants described it as a virus part of an orchestration by governments to reduce the population.

One of the key task of the pastor is to interpret the text and the context for the sake of understanding God's will. In this endeavour, one needs to be careful and give interpretation that is in line with church universal and helpful for the welfare of humanity. It is interesting to realise that majority of the participants adhered to scientific understanding of the coronavirus instead of perpetuating the conspiracy theories about the virus. But, how did the coronavirus affect the ministerial structure of the church?

\section{In terms of restructuring of the church in the context of the coronavirus pandemic}

The outbreak of the coronavirus pandemic in South Africa has challenged the church leaders to reimagine the ministry. We assume that in the process of reimagination, there was some restructuring that was envisaged that compelled the church and congregations to shift from the usual way of engaging ministry towards a new approach. The authors observed few structural changes in the participating congregations. There seems to be a shift from a maintenance model of ministry towards a ministry that promotes growth in various aspects of ministry. A church in maintenance mode is a church that ignores its calling in the world, lost its relevance and entangled in spiritual stagnancy because of its obsession with institutional matters. For instance, Pillay (2017:36) states that a 'missional church' paradigm, goes beyond the church's interest, but God's interests, and to transform the world that it reflects God's Kingdom and his sovereign rule. In order to attain some clarity on the situation in the congregations of our participants since the existence of the coronavirus pandemic, we asked the participants whether during the pandemic their congregations remained in maintenance mode or were anticipating growth in their respective congregations. The majority of the participants reported that they remained in maintenance mode, because they were losing members, and in other instances there was a lack of numerical growth during the period, and therefore the congregations became more 'inward' looking. Other participants said that their congregations were either declining or growing. The reasons for declining were poor attendance of worship services, loss of membership to new churches, as well as the fear of contracting the virus, which is related to the public opinion that church gatherings are super-spreader events. The reasons for growth could be attributed to regular workshops and care given to members of their congregations. It is true that the coronavirus pandemic adversely affected the church ministry severely even to this date. But, it is true that the participants' churches struggled with maintenance mode or managed to allow the Holy Spirit to direct the church to be creative through the use of technology to spread the gospel and reviving the practice of family worship service. It is also true that the church leaders empowered their members, which had to conduct the service in their homes that were mostly the responsibility of the leader of the church, and therefore the church leaders were challenged to function differently, not authoritative and top-down, but relational, facilitative, and spiritual, ... not mostly a 'public performer, but that of a networker, teambuilder, spiritual director' (Doornenbal 2012:7).

In the process of restructuring, there is also a need to assess whether there is a shift from dominance of one culture and ethnic group towards inter-racial and inter-cultural church that is open to other ethnic groups, languages and cultures. In light of this, we asked participants a question on what ethnic group dominates their membership and for how long (we gave them the option of choosing from 10 years, 20 years and more than 30 years) have their churches being in existence. The background to such a question is that South African churches had been historically aligned according to race and mission was from the white community to black community and foreigners were not even part of fulfilling the mission of God for many of the township congregations. In response to the questions, the majority of the participants indicated that their churches existed for more than 30 years, others 20 years and some 10 years. Concerning the identity of their membership, almost all the participants indicated their membership as predominantly Africans. The above response 
indicates that there is a need to enquire further from the participants why in this new dispensations in South Africa do we still have churches that are classified according to race and culture, and what efforts are done to shift towards nonracial congregations.

Restructuring in a church can be hindered by clergy centred ministry characterised by passive lay people who are dependent on the church leader (cf. Bosch 1991). ${ }^{6}$ According to Niemandt (2010) the 'missional church' paradigm encouraged a church that is structured in such a way that the lay people are empowered. In support the church leader enjoys being the dominant person offering spiritual services of ministry. To find out whether the ministry of the participants is clergy centred or centred around church members and lay people who imagine themselves as the ones who must fulfil the prophetic role, we asked the participants if their membership is either clergy centred or centred around church members who are willing to play their prophetic role in their context. During the pandemic, there were various moments that could have been utilised to change the structure of churches in this regard, especially during the lockdown, where lay people in their families had to take responsibility for their spirituality and church services. In response to this question, the majority of the participants reported that their church members had opportunities to minister in their churches according to their own spiritual gifts whilst few of the participants mentioned that their ministry is still centred around the church leader. Following the response of the majority of the participants saying their ministry gives opportunity to members of the church to express spiritual gifts, we asked the participants whether they do have workshops to empower their members of the church for both ministry inside and beyond the church. In response, almost all the participants agreed that they do workshops in their congregations. Majority of the workshops focused on leadership development for different members of the church in the category of youths, women and men's fellowship. Other themes engaged in the workshops are those related to church administration, marriage, spirituality, fundraising and the role of church in society. In our observation of the above, the focus of the workshops seems to cover a variety of themes related to internal and external ministry of the church. However, more enquiry needs to be done to find out what really entails leadership training and to what extent are congregation members empowered for their social involvement.

In the restructuring process of the church, worship services must not be left behind because the missional worship service must empower members of the church to embrace strangers, and reach out to the world. As a result, we asked the participants questions such as how many worship services do they have on Sundays and that what is the focus of such worship services. The response of the majority of the participants was that they have only one worship service on Sundays. It is the pastor who mostly leads the worship 6.See in particular Bosch's (1991) discussion on 'Mission as the Whole People of God'. services, and if he is not present, it is the lay leaders. On the second question, the majority of the participants mentioned that the focus of the worship services is both for personal holiness and responsible involvement in the society.

One should appreciate more the above-mentioned focus of worship service but further enquiry is needed to understand how personal holiness and responsible involvement in the society contribute to effective missional practices.

Restructuring within congregations can be because of internal or external factors that affect the normal function of the congregation. The coronavirus pandemic is one of the external factors that, in a period of a year, affected churches in a variety of ways. In order to verify this, we asked participants whether in the last two years their churches experienced any significant changes during their worship services in line with internal or external influence. Majority of the participants agreed that there were some changes that occurred and that were because of existence of the lockdown induced by the COVID-19 pandemic. The subsequent changes were mentioned, for instance, the loss of place of worship because of the lack of income and the change in terms of the approach to worship services. Besides changes brought by the coronavirus pandemic, few of the participants mentioned they incurred a schism in their congregations as one of the main changes that occurred in the last two years in their congregations. In light of the above, it is true that change in a congregation can be brought by internal or external factors. However, the crucial question is how churches engage those changes. Do they embrace those changes for the benefit of ministry or do they reject them and live in denial of existence of those changes? In our observation and response to the above, majority of churches in the Mangaung township during lockdown period embraced new changes by exploiting the opportunities of using technology such as social media, radio or television for proclaiming the gospel, counselling and reaching out to those in need. However, we acknowledge as well that there were some churches that remained closed and did not do much in terms of exploiting new changes of using technology to reach out to those in need. Instead, they waited for the time when the COVID-19 pandemic would decline and the churches be given the opportunity to worship again in their buildings.

Because the coronavirus pandemic has affected churches in many ways, what kind of challenges did it expose the churches to, that compelled them to restructure their ministries? To find out the answer to this question, we asked the participants what main challenges they experienced because of the impact of the coronavirus pandemic. Concerning the challenges brought by the coronavirus pandemic, the majority of the participants reported that economically the coronavirus pandemic caused an increase in unemployment and a decline of income for the church. Psychologically, the coronavirus pandemic made people scared to come to church, because they feared to contract the coronavirus at the church, and eventually some suffered 
because of a lack of social contact and loss of family members. Spiritually, it led to a decline in church attendance of the worship services, discontinued house visitations, interrupted church programmes and adversely affected the spirituality of some members of the church. In terms of physical health, some members of the churches contracted the virus and the vulnerable members (elderly members of the congregation and those with chronic diseases) were advised not to attend the church services. Socially, the coronavirus pandemic resulted in physical distancing between people and the wearing of masks by members hindered effective communication as well as fully expressing themselves through singing during worship services. The above facts indicate enormous and overwhelming impact of the coronavirus pandemic on the church, and for the church to have survived it is by grace of the Lord.

In light of the above discussions under restructuring, we expect that the churches and church leaders under the inspiration of the Holy Spirit would find innovative ways to restructure their ministries faced by the plethora of challenges induced by the presence of the coronavirus pandemic. Therefore, we asked our participants the following question: 'What new and creative experience(s) did you have in your congregations concerning the impact of the coronavirus pandemic?'. In response, the participants reported those new and creative experiences like, new practices of doing worship services online and conducting sacraments through the use of protective equipment including gloves. Maintaining social distancing reduced the attendance in the churches and limited the duration of the funeral services, but it gave rise to the revival of household worship services. For the sake of physical well-being, members were encouraged to observe the COVID-19 regulations by wearing masks and keeping social distancing whilst staying healthy at all times. Economically, the people commenced with the planting of gardens and the distribution of food parcels to those in need. Technologically, the coronavirus pandemic encouraged the use of social media for worship services, communication, meetings and workshops. These were some of the innovation and restructuring that occurred within the churches. The above discussion is an indication that majority of the participants' churches embraced the changes brought by the coronavirus. In embracing these changes, one could say it was an appreciation of the creative role of the Holy Spirit that guided the churches towards unique ways of doing and reviving the ministerial practices.

Lastly, the coronavirus pandemic disrupted the physical gathering of believers but on the other hand, more positively it compelled the churches to reach out to those in need and confronting the injustices in the society. In order to determine whether the churches restructured themselves well in this regard, we asked the participants the following questions: 'Do you think a church should be involved in the community? How does your congregation reach out?' In response to the first question, all the participants conceded that congregations must be involved in the community. On the second question, majority of the participants reported that involvement in the community is part of their missional identity and should not be regarded as a separate action of mission. These responses are indeed inspiring and prompted us that, if participants reported that there were not only moments of re-imagination but also restructuring through paradigm shift, there is much hope for the prophetic ministry of the township churches in the Mangaung District Municipality.

\section{Missional as prophetic praxis during the coronavirus pandemic}

Concerning prophetic involvement in society, we expect the participants to understand themselves as people sent by God to act prophetically through life and worship of the church. We assume that their prophetic role in society will shape their lives to be one that demonstrates service, integrity, to be in dialogue with their respective context, and confront injustices that occur on a daily basis. In relation to the prophetic involvement, the participants were asked various questions such as, what kind of community projects are they involved with, who is involved in those projects, and who are the beneficiaries of those projects. In response, the participants reported that in their community development projects it is the members of their congregations who are mostly involved and beneficiaries include members of the community and its leaders.

According to Korten's theory (1984), community development can be classified as development that addresses immediate needs, development that contributes to community projects that are sustainable, development that empowers one to challenge policies that hinders effective development in the community and lastly it is the kind of development that leads one to be an activist within people movements that challenge evil system and structures and fight for the rights of a particular group of people. In the context of the participants, we realised that their community development projects are mostly ones that addresses the immediate needs of their community in the form of the distribution of food, clothes, counselling, and care of the poor, elderly, orphans and the homeless. There are those who do projects for sustainable development, for instance, the training of people to acquire the necessary skills to be able to establish gardens, to empower also people spiritually in order to support others as well as improving their education level.

In the quest to understand whether the church would perform such purposes, the study found that the participating churches are in some way involved in training and education, as well as empowerment of their members. However, from the researchers' perspective, the majority of participants in the township of Mangaung are involved in the minister fraternals. Some of these minister fraternals do function on the various levels of community development initiatives. Nevertheless, before and during the lockdown only a few of the minister fraternals were much involved in the process of registering churches as NGOs, enabling them to commence with their own projects to generate income for sustainability 
purposes and even distributing food parcels to those in need, especially during the lockdown period.

Most importantly, as positioning themselves prophetically, during the lockdown period it is reported that some of these minister fraternals challenged the policies of the government against the closure of churches, the gathering of people inside and outside the church buildings, and the classification of essential workers. This eventually led to the churches being able to open their buildings, and to be classified as essential services to members of the community.

They even advised the South African government that the gathering of people inside the church building should be $50 \%$ of the capacity of the building of the church - which was ultimately granted by the president in a subsequent address to the nation. Lastly, these minister fraternals also challenged the government to regard church leaders as essential workers who must be given permits to work and travel freely during the lockdown period. In light of the above, through minister fraternals, some church leaders did contribute to the development of the community on the level of policy development and people movement. Further research may be needed to find out whether this kind of involvement on such high level was in line with the fact that churches were directly affected and challenged during lockdown period or it is a sustainable practice even beyond the lockdown period. However, it is clear that the churches were not only re-imagining or restructuring at certain levels, but also there was a measure of 'prophetic' positioning and praxis that was evident during the coronavirus pandemic.

\section{Missional Ecclesiology and the coronavirus in the ministry of the township congregations in Mangaung}

The coronavirus pandemic has affected various aspects of human existence within and beyond church boundaries. In order to understand this, we asked our participants on how the coronavirus pandemic affected their spirituality, their view on healing and health, their socio-economic situation, their social relations and the relationship between church and state. With regard to their spirituality, the participants reported that the challenges brought by the coronavirus pandemic generally prompted them to develop an increased faith and intimacy with God. In addition, they reported that it prompted the churches and members of the community to respect the regulations of the government as mentioned in Romans 13:1. It made others to be critical, asking why God did allow this coronavirus to challenge the church of God. It is evident that there developed a deeper and intimate relationship between members of churches and God - and their experience of God as an immanent God.

In the context of South Africa, before the outbreak of the coronavirus pandemic, there were numerous reports about pastors involved in scandals of healing and resurrecting people from death (Makhudu 2018). But, immediately during the lockdown in South Africa, all that disappeared and not much was heard of the church leaders healing people in particular from the coronavirus pandemic. In fact, in Bloemfontein some churches and pastors were blamed for spreading the coronavirus in the area of Bloemfontein (Shange 2020). In response to how the pandemic affected the healing ministry and health in general, the participants responded as follows:

'The setback it brought was that it rattled our faith, instilled fear hopelessness and panic amongst Christians and hindered pastors from laying hands in prayer to the sick in the practice of its healing ministry. The ultimate results of this were that churches lost some members in the process and others managed to be healed through prayers of the churches. In contrast, the positive developments concerning health and healing brought by the coronavirus pandemic were revival of our faithfulness in God for healing and reassuring us that nothing, including the coronavirus, is bigger than our God. In addition, it highlighted the importance of observing regulations concerning health and safety measures, appreciating our health workers, and the significance of prayer and the Word in times of stress brought by coronavirus pandemic.' (Participants P2, P3, P8 and P12 on question 8.2)

During lockdown in South Africa, many businesses suffered and lost income to such an extent that some had to close down. The participants were asked to explain how the coronavirus pandemic affected the economic situation of their congregations. Majority of the participants responded that it affected them very badly because numerous church members were retrenched, and congregations suffered a loss of income to such an extent that they could not remunerate their pastors, care for the poor and even purchase materials necessary to comply with the COVID-19 regulations.

The Christian religion is a religion that emphasises relationship and intimacy through hugging, holy kiss, and touching. However, all of this could no longer be practised, because congregation members had to observe COVID-19 safety measures of wearing masks and keeping social distancing. When asked about how the pandemic affected the social relationship amongst members of their congregations, the pastors responded that it created problems in worship service, in such a way that socialisation in the form of physical contact was kept to a minimum, for example, there was no longer hugging and laying of hands and the attendance of worship service has decreased because of fear of contracting the virus. Outside the worship service, there were no more or limited house visits. Communication and singing within and beyond worship services were adversely affected by the wearing of masks. However, positively, the participants mentioned that the coronavirus pandemic brought an increase in the uses of online services for communication, meeting and worship service, especially during strict lockdown period. Most importantly, the coronavirus pandemic brought strong bond amongst the members whereby they supported each other more than ever before. 
The relationship between the church and the state has been an ambiguous one in the context of South Africa and the other countries in the world. In South Africa, we had relationship of the churches and state which reflects the church in critical solidarity with the state. Participants were asked about how the pandemic influenced their view on the relation between the church and the state. The participants applauded cooperation of the state with churches, appreciated efforts made by the state to alleviate negative impact of the pandemic on the society and even suggested that people must obey authorities. The negative responses given were: Even though the church was acknowledged by the state as offering essential services and pastors as frontline workers, the state had a weakness of not respecting the church by being domineering and ignorant of the church when it made decisions concerning the church. For example, for several times during the lockdown, the state permitted only 50 people in a building instead of allowing $50 \%$ of the capacity of the building of the church with social distancing in mind. Again, the state excluded the church leaders to benefit from the COVID-19 relief fund. As a result, the participants concluded that the state does not care about the church, and that it does not consider advices of the church leaders. Therefore, according to them, churches should be vigilant against the state and maintain its independence from the state.

\section{Conclusion}

In conclusion, it seems plausible to suggest that there was indeed a process of re-imagining on various fronts for the participating churches in this study. For example, the majority of the participant churches did reflect on positive reimagining of the church, mission and the coronavirus pandemic. This became evident through the positive definitions where reference was made particularly to the church as the Body of Christ, mission centred around God and involving preaching the gospel and social involvement. Lastly, it was inspiring to observe the congregations' and church leaders' movement in defining the coronavirus scientifically rather than propagating the conspiracy theories.

The extent to which the churches allowed itself towards restructuring remains a challenge. This is evident in the report of the participants agreeing that their congregations' ministry is in maintenance mode because of the coronavirus impact and internal division. Nevertheless, the manner in which the participants' congregations responded to the coronavirus pandemic by conducting workshops to empower the laity, offering balanced worship services that emphasised both personal piety and responsible social involvement and embracing the changes brought by coronavirus pandemic, through hybrid (online and physical) worship services, gave hope that congregations in Mangaung township at least allowed some restructuring to occur in their missional ministry, to some certain extent (cf. Pillay 2017).

The prophetic stance and positioning during the coronavirus pandemic were in many instances compromised by enormous challenges experienced by participants' churches. However, there are indeed instances where one could be able to see the positive development, whereby lay people were involved to reach out to those in need during the coronavirus pandemic. Lastly, missional practice, especially on responsible social involvement was enhanced by ecumenical involvement of participants in various minister fraternals which challenged government's view on the role of the church and pastors during the coronavirus pandemic. The churches in the townships also challenged the state with their protocols and policies, regarding the coronavirus pandemic, when it would endanger the spiritual life of the congregants. Therefore, the churches were not passive, but acted in accordance with God's mission for the church. Thus, the COVID-19 pandemic, as a unique challenge for the church, enhanced the missional character of the churches in the Mangaung District Municipality. It should be stated that the church's compliance with COVID-19 protocols in most of the congregations, speaks volumes to the movement of the churches - being prophetic, and missional in becoming concerned not only in the saving of souls of people, growing their church, but also in 'saving lives' as Burger (2017:27) argues, which is intrinsic of the missional character of a church.

\section{Acknowledgements Competing interests}

The authors declare that they have no financial or personal relationships that may have inappropriately influenced them in writing this article.

\section{Authors' contributions}

Both authors contributed equally to this work.

\section{Ethical considerations}

The Research Ethics Committee of the University of the Free State provided ethical clearance for the project. UFS HSD 2018/1075

\section{Funding information}

This research received no specific grant from any funding agency in the public, commercial or not-for-profit sectors.

\section{Data availability}

Data sharing is not applicable to this article as no new data were created or analysed in this study.

\section{Disclaimer}

The views and opinions expressed in this article are those of the authors and do not necessarily reflect the official policy or position of any affiliated agency of the authors.

\section{References}

Baron, E. \& Botha, N., 2020, Obedience and servant leadership. Apollis, appies, Buti, Buys, Sonbonani Scholar, Bloemfontein. 
Baron, E. \& Maponya, M.S., 2020, 'The recovery of the prophetic voice of the church: The adoption of a "missional church" imagination', Verbum Et Ecclesia 41(1), 1-9. https://doi.org/10.4102/ve.v41i1.2077

Bevans, S.B. \& Schroeder, R.P., 2004, Constants in context. A theology of mission for today, Orbis Books, New York, NY.

Bosch, D.J., 1991, Transforming mission. Paradigm shifts in theology of mission. Twentieth Anniversary Edition, Orbis Books, New York, NY.

Burger, C., 2017, 'Why we need the missional conversation in South Africa Now', in C. Burger, F. Marais \& D. Mouton (eds.), Cultivating missional change. The future of missional churches and missional theology, pp. 20-34, Bybelkor, Wellington.

Cray, G., 2017, 'The journey towards "missional" in the United Kingdom. The history and development of the missional movement in the United Kingdom', in C. Burger, F. Marais \& D. Mouton (eds.), Cultivating missional change. The future of missional churches and missional theology, pp. 92-106, Bybelmedia, Wellington.

Department of Health, 2021, COVID-19, Department of Health, viewed 17 February 2021, from health.gov.za/covid19/.

Doornenbal, R., 2012, Crossroad. An exploration of the Emerging-Missiona conversation with a special focus on missional leadership and its challenges to theological education, Eburon Academic Publisher, Delft.

Dulles, A.C., 2002, Models of the church, Doubleday, New York, NY.

Guder, D.L. (ed.), 1998, Missional church. A vision for the sending of the church in North America, WB. Eerdmans, Grand Rapids, MI.

Hendriks, H.J., 2004, Studying congregations in Africa, Paarl Print, Paarl.

Korten, D., 1984, People-centred development. Contributions toward theory and planning frameworks, Kumarian Press, Sterling, VA.

Kritzinger, J.N.J., 2012, 'Overcoming theological voicelessness in the new millennium' Missionalia 3, 233-250.

Makhudu, T., 2018, Five religious scandals that rocked South Africa, viewed 12 June 2021, from https://www.news24.com/drum/News/five-religious-scandals-thatrocked-south-africa-20180125.

Makofane, K. \& Botha, N., 2019, 'Christianity and social transformation in postapartheid South Africa: From prophetic quietism to signs of prophetic recovery', Acta Theologica 28(6), 88-103.

Maluleke, T.S., 2001, 'The challenge of HIV/AIDS for theological education in Africa towards an HIV/AIDS sensitive curriculum', Missionalia 29(2)125-143.
Marais, F., 2017, 'The history and challenge of the missional movement in South Africa. Perspectives from an insider', in C. Burger, F. Marais \& D. Mouton (eds.) Cultivating missional change. The future of missional churches and missional theology, pp. 64-79, Bybelkor, Wellington.

Masenya, M., 2001, 'Between unjust suffering and the "silent" God. Job and HIV/AIDS sufferers in South Africa', Missionalia 29(2), 186-199.

Masuku, T.M., 2014, 'Prophetic mission of faith communities during apartheid South Africa, 1948-1994: An agenda for a prophetic mission praxis in the democratic SA', Missionalia 42(3), 151-167. https://doi.org/10.7832/42-3-66

Mboya, R., 2010, 'A local church's holistic response to HIV/AIDS', Missionalia: Southern African Journal of Theology 1(38), 121-141.

NGSK, 1986, 'Moderatuur Sinode, Belhar 1986', Die Ligdraer, 16 October, p. 1.

Niemandt, C.J.P., 2010, 'Five years of missional church - Reflections on missional ecclesiology', Missionalia 38(3), 397-413.

Niemandt, C.J.P., 2014, 'Developing missional congregations', Paper Presented at the Council for World Mission Africa Region Assembly, Johannesburg.

Pillay, V., 2017, 'The missional renaissance. Its impact on churches in South Africa, ecumenical organisations, and the development of local congregations', in C. Burger, F. Marais \& D. Mouton (eds.), Cultivating missional change. The future of missional churches and missional theology, Bybelkor, Wellington.

Shange, N., 2020, Covid-19: Bloemfontein church that hosted infected guests says they were screened on arrival in SA, viewed 12 June 2021, from https://www.timeslive. co.za/news/south-africa/2020-03-24-covid-19-bloemfontein-church-that-hostedinfected-guests-says-they-were-screened-on-arrival-in-sa/.

Smith, N., 2002, 'From Missio Dei to Missio Hominum. En route in Christian mission and missiology', in M. Karecki (ed.), The making of an African person: Essays in honour of Willem Saayman, pp. 4-21, South African Missiological Society, Pretoria.

Stiebert, J., 2001, 'Does the Hebrew Bible have anything to tell us about HIVAIDS?', Missionalia: Southern African Journal of Theology 29(2), 174-185.

World Health Organization (WHO), 2020a, Impact of COVID-19 on people's livelihoods, their health and our food systems, viewed 18 February 2021, from who.int/news/ item/13-10-2020/impact-of-covid-19-on-people's-livelihoods-their-health-andour-food-systems.

World Health Organization (WHO), 2020b, Practical considerations and recommendation for Religious Leaders and Faith Based Communities in the context of Covid-19, for Religious Leaders and Faith Based Communities in the context of Covid-19,
viewed 17 February 2020, from WHO-2019-nCOV--Religious_Leaders-2020.1-eng. 